\title{
PODÍL SVAZU ČESKOSLOVENSKÝCH MUZEÍ A ASOCIACE MUZEÍ A GALERIÍ ČR NA PŘÍPRAVÁCH OBECNÉ ZÁKONNÉ NORMY PRO OBLAST MUZEJNICTVÍ
}

\section{LUDĚK BENEŠ}

\section{ABSTRAKT/ABSTRACT:}

Svaz československých (českých) muzeí navázal ve svých legislativních snahách na aktivity Karla Václav Adámka z přelomu 19. a 20. století. Po celé období první republiky i na počátku protektorátu se neúspěšně pokoušel prosadit bud' samostatný muzejní zákon nebo alespoň začlenění muzejní problematiky do zákona o ochraně památek či archivního zákona. Ve svém úsilí pokračoval i po roce 1945 . Na konci 40. let připravil ucelený návrh zákona o muzeích a galeriích, který však byl novým komunistickým vedením zamítnut. V 50. letech byla činnost Svazu postupně omezována a jeho vliv na přípravu muzejní legislativy postupně klesal. Na přípravě zákona č. 54/1959 Sb. o muzeích a galeriích se již prakticky nepodílel.

Na činnost Svazu se snaží navázat od 90. let 20. století Asociace muzeí a galerií ČR. Po roce 2000 se aktivně zapojila nejprve do přípravy systému registrace a akreditace muzeí a ke konci druhého desetiletí se výraznou měrou podílí na přípravě samostatného muzejního zákona.

The role of Association of Czechoslovak Museums and Czech Association of Museums and Galleries in development of museum legislation
Legislative efforts of the Association of Czechoslovak (Czech) Museums followed the activities of Karel Václav Adámek from the turn of 19 th/20th century. During the whole period of the First Czechoslovak Republic and at the beginning of the Protectorate of Bohemia and Moravia, the Association unsuccessfully strived for a separate Museum Act or at least for inclusion of the museum sphere into the Monument Act or Archival Act. These efforts also continued after 1945. At the end of the 1940s, the Association elaborated a complex proposal for an Act on Museums and Galleries, which was then rejected by the new communist government. The activity of the Association has gradually been more and more limited in the 1950s and its influence on development of museum legislation has diminished. Its participation in development of the Act No. 54/1959 Coll. on museums and galleries was as good as zero. Since the 1990s, the Czech Association of Museums and Galleries tries to continue the activities of the Association of Czechoslovak Museums. After 2000 it began to actively participate in development of a museum registration and accreditation system and at the end of the second decade of the 21 st century it participates to a considerable extent in creation of a separate Museum Act.

\section{KLÍČOVÁ SLOVA/KEYWORDS:}

zákon o muzeích - Svaz

československých muzeí - Asociace muzeí a galerií ČR

Museum Act - Association of Czechoslovak Museums - Czech

Association of Museums and Galleries

\section{Úvod}

Mým prvotním úmyslem v době, kdy jsem začínal práci na tomto textu, bylo zmapovat přínos Svazu československých muzeí (původně Svaz československých muzeí vlastivědných, od roku 1939 Svaz českých muzeí) k přípravě zákona, jenž by obsáhl a upravil oblast muzejnictví a dal tak muzeím vhodný právní podklad pro jejich další existenci a činnost. Brzy se však ukázalo, že počáteční záměr zmapovat léta 1919-1945 bude třeba časově rozšířit, ${ }^{1}$ protože legislativní snahy Svazu do značné míry vrcholily až koncem 40. let 20. století a přes postupné omezování činnosti této profesní organizace zcela

1 Pomineme-li několik drobných statí, začlenil vývoj českého muzejnictví i Svazu československých muzeí jako jeho vrcholného orgánu v období let 1919-1945 ve větší míře do svých monografií pouze Jiří Špét, ani on však nevěnoval legislativní činnosti Svazu širší pozornost. ŠPÉT, Jiří. Muzea ve vývoji společnosti a národní kultury. Praha, 1983; ŠPÉT, Jiří. Přehled vývoje českého muzejnictví I. (do roku 1945). Brno: Masarykova univerzita, 2003. 
neustaly ani v 50. letech. Zároveň však, i na podnět redakční rady časopisu Museologica Brunensia, postupně zrála myšlenka připojit $\mathrm{k}$ původnímu textu i příspěvek o podílu Asociace muzeí a galerií České republiky (dále také jako AMG) na probíhající přípravě nového zákona o muzeích a vytvořit tak základní přehled vývoje snah usilujících o vydání základního právního předpisu pro obor muzejnictví na území českých zemí. Při své analýze jsem tedy musel překlenout téměř šedesátileté období od vydání zákona č. 54/1959 Sb. o muzeích a galeriích do konce prvního desetiletí 21. století, kdy byla zahájena diskuse nejprve o přípravě systému registrace a akreditace muzeí. Chci zdůraznit, že jsem se ve svém článku úmyslně nevěnoval přípravě, realizaci a aplikování zákona č. 122/2000 Sb. o ochraně sbírek muzejní povahy, který se týká především muzejních sbírek, nikoliv činnosti muzejních institucí.

\section{Pokusy o legislativní podchycení památkové péče a muzeí v období rakousko-uherské monarchie}

$\mathrm{V}$ roce 1873 byla při předlitavské Centrální komisi pro ochranu památek zřízena nová speciální komise, která byla pověřena prací na přípravě uceleného zákona o památkách. Teprve v roce 1898 se však podařilo sestavit solidní návrh zákona, který se však nepodařilo prosadit na jednání panské sněmovny říšské rady. Do prvního čtení se tak návrh dostal až v roce 1909. Tehdy však byly vưči němu vzneseny vážné a početné námitky byl vrácen komisi k přepracování s tím, že k jeho projednání by mělo dojít v roce 1911. Zákon měl podchytit ochranu movitých i nemovitých památek, přičemž tuto ochranu měly vykonávat politické úřady, které $\mathrm{v}$ této oblasti měly být podřízeny Ministerstvu kultu a vyučování. Zásadním podkladem pro jejich činnost se měly stát soupisy památek, pořízené památkovými úřady řízenými centrální památkovou komisí a zemskými památkovými úřady. Zákon se měl týkat pouze památek ve veřejném vlastnictví a v majetku církví (zde však pouze se souhlasem příslušných církevních úřadů). Na památky v soukromém majetku se měl vztahovat pouze $\mathrm{v}$ případě, že s tím budou souhlasit jejich vlastníci. Zahrnoval by tedy jen část tehdejších muzejních sbírek. $\mathrm{V}$ případě nutnosti však měl poskytovat možnost vyvlastnění památky státem. V návrhu zákona bylo myšleno i na archeologické památky. K jeho realizaci však nikdy nedošlo, další projednávání zmařila 1. světová válka. ${ }^{2}$

O něco dál, avšak posléze se stejným výsledkem, se dostala příprava obdobného zákona na zemské úrovni. Myšlenka nezbytnosti zákona, jenž by poskytl ochranu celé škále památkových objektů a i cenných historických předmětů (zejména $\mathrm{v}$ muzejních sbírkách), kvasila mezi českými muzejníky několik desetiletí. V 90. letech 19. století se jí ujal poslanec Zemského sněmu Karel Václav Adámek, který se svým legislativním návrhem vystoupil poprvé na zasedání Zemského sněmu pro Království České 15. března 1892. Dle jeho představy měl vzniknout zákon o zřízení zemské komise na ochranu památek, jež by měla fungovat jako poradní orgán zemského výboru. Podstatu její činnosti by tvořil dohled nad činností okresních a místních památkových komisí. Adámkův návrh však byl zamítnut. ${ }^{3}$

\footnotetext{
2 CÁSEK, Jiří. Vývoj právní regulace památkové péče [online]. Brno: Masarykova univerzita, Právnická fakulta, 2016/2017, s. 21 [cit. 2020-0417]. Dostupný z www: <is.muni.cz/th/wzrvd/ Diplomova-práce_-_elektronicka_verze.pdf $>$. Diplomová práce.

3 Český lid [online]. 1894, roč. III, s. 372-373 [cit. 2020-04-17]. Dostupný z www:
}

Jeho úsilí bylo následně podpořeno na I. sjezdu muzejních spolků, odborů Národopisné výstavy a přátel české vlastivědy, který proběhl 15. srpna1893 v Hlinsku. Závěrečné usnesení sjezdu obsahovalo jako bod č. 1: „vydat zákon o komisi na ochranu památek podle návrhu poslance K. V. Adámka z 15. března 1892, která by řídila odbornou památkovou a muzejní činnost a byla by poradním orgánem zemského výboru“. Bod č. 2 pak zněl takto: „Co nejdřive zahájit jednání o vydání zákona proti vývozu národopisných a uměleckých památek."4

Další pokus učinil Adámek na dvou po sobě následujících zasedáních zemského sněmu, a to 28. prosince 1893 a 15. ledna 1894. Poukázal tehdy na příslušné zákony či podzákonné legislativní normy, které byly nedávno schváleny v jiných zemích monarchie, zejména na nový uherský zákon. Jeho snaha se setkala pouze s částečným úspěchem. K přijetí zákona sice nedošlo, nicméně bylo alespoň schváleno ustavení zemské památkové komise, i když fungující bez legislativního podkladu. ${ }^{5}$

Adámek a jeho spolupracovníci však ve svém úsilí nepolevovali ani nadále. Na II. sjezdu českých archeologů a muzejních spolků, který se konal v Kutné Hoře 28. srpna 1898, přednesl Adámek rozsáhlý úvodní referát, v němž znovu připomenul, že vytvoření památkového zákona musí i nadále zůstat jedním z hlavních cílů českých muzejníků. Kromě památkového zákona by měl

\footnotetext{
<www.nulk.cz/ek-obsah/ceskylid-html/ ceskylid03>.

4 HROMÁDKOVÁ, Kateřina. Karel Václav Adámek a jeho činnost muzejní a muzeologická [online]. Pardubice: Univerzita Pardubice, Filozofická fakulta, 2007/2008, s. 97 [cit. 202004-17]. Dostupný z www: <dk.upc.cz/ bitstream/handle/10195/19389(HromadkovaK_ kabel\%20 Vaclav_FS_2008.

pdf? sequence $=1$ isAlcrved $=y>$. Diplomová práce 5 Tamtéž, s. 68.
} 
vzniknout také zákon o zákazu vývozu památek a případně i samostatný zákona na ochranu stavebních památek a jejich součástí. Se stejným námětem Adámek vystoupil také na III. sjezdu v Praze v roce 1908. $\mathrm{V}$ rámci muzejní sekce sjezdu byla na jeho návrh vydána rezoluce, která obsahovala i požadavek „Co nejdřive uzákonit návrh na záchranu památek “. ${ }^{6}$ Jak je všeobecně známo, ani tato výzva se nesetkala s pozitivním ohlasem a obdobný zemský zákon nikdy nevznikl.

\section{Legislativní aktivity Svazu československých muzeí v letech 1919-1945}

Svaz československých muzeí (nadále jen Svaz) ${ }^{7}$ považoval od počátku své existence v roce 1919 vydání muzejního zákona za jeden ze svých hlavních úkoli̊. Z nového zákona a s ním souvisejících vládních nařízení mělo navíc vyplynout ustavení regulérní muzejní sítě, nezávisející nadále na pouhé vůli státu, územních celků, měst a obcí či spolků a jednotlivců. Toto úsilí však nenacházelo pochopení a zejména politickou vůli na Ministerstvu školství a národní osvěty (MŠANO), kde bylo příslušnými úředníky prosazováno pojetí zahrnující muzejnictví pod širší zákon o památkách či archivech, jejichž přijetí se zdálo být průchodnější. Tento názor občas sdílelo i předsednictvo Svazu, resp. alespoň jeho část, což potvrzuje např. požadavek prof. Zvěřiny na schůzi 6. srpna 1921, aby byl co nejdříve vydán zákon na ochranu památek. Jeho žádost však byla zdůvodněna především stávajícím velkým nebezpečím prodeje

\footnotetext{
6 Tamtéž, s. 97

7 Pod tímto názvem působil svaz teprve od roku 1924, do té doby nesl název Svaz vlastivědných muzeí českých. K původnímu názvu (s vypuštěním slova „vlastivědných“) se vrátil na podzim 1939 v souvislosti s vyhlášením autonomie Slovenska po uzavření Mnichovské dohody. Rozdělení svazu na českou a slovenskou část trvalo až do jeho zrušení v roce 1960.
}

soukromých sbírek do zahraničí. ${ }^{8}$ Otázka samostatného muzejního zákona však znovu vyvstala v diskusi na valném shromáždění Svazu, které se konalo 5. srpna 1922. V zápise z jednání, resp. v závěrečné rezoluci, se však přímo neobjevila; byl zde zmíněn pouze požadavek, „aby podobně jak je v našem knihovnictví, bylo i muzejnictví zákonem podepřeno, $a$ aby vláda $v$ rámci př́štího památkového zákona uložila samosprávným svazkům povinnost udržovati muzea, zajistiti jejich stav a pracovní postup“. 9

V dalších letech zřejmě probíhala občasná jednání s MŠANO o této záležitosti, nelze to však konstatovat bez výhrad, nebot' k tomu chybějí potřebné podklady. Víme jen, že na Valné hromadě Svazu v Olomouci 23. května 1926 úředník MŠANO a pracovník památkové péče Zdeněk Wirth, ${ }^{10}$ prosazoval těsnou spolupráci muzeí s archivy i orgány památkové péče, což by umožnilo rozvíjet komplexní vlastivědnou činnost. Ve svém projevu mj. navrhnul zřízení ústředních památkových ústavů, v nichž by se soustřed’ovala vědecká práce na poli památkové péče i muzejnictví a které by byly vybaveny dostatkem finančních prostředků stejně jako potřebnou výší technických a personálních kapacit. Těmito „památkovými ústavy“ však mínil státní a zemská muzea. Muzejní sít by doplňovala specializovaná oborová muzea opřená o zákonnou normu, jež by řešila problematiku ochrany památek v muzeích a jejich

\footnotetext{
8 Archiv Národního muzea, fond Svaz československých muzeí, kart. 55. Zápis ze schůze předsednictva Svazu vlastivědných muzeí českých ze dne 6. 8. 1921.

9 Archiv Národního muzea, fond Svaz československých muzeí, kart. 55. Zápis z Valné hromady Svazu vlastivědných muzeí českých ze dne 5. 8. 1922.

10 Zdeněk Wirth, 1878-1961, historik umění, vysokoškolský pedagog, od 1923 přednosta osvětového odboru Ministerstva školství a národní osvěty.
}

vzájemných vztahů. Jádro této nové sítě měly tvořit státní ústavy, a sice Národní muzeum, vybavené mj. konzervátorskou laboratoří pro celý stát, ${ }^{11}$ Státní galerie, ${ }^{12}$ Archeologický ústav a Fotografický ústav. K nim by byla přrirazena také postátněná zemská muzea (moravské a slezské), přičemž $\mathrm{k}$ těm dosavadním by přibylo i nově založené zemské muzeum na Slovensku. Přičleněna by byla rovněž specializovaná oborová muzea, jejichž existence i činnost by se opírala o zákon řešící oblasti ochrany památek a muzejnictví a jejich vzájemné vztahy. K realizaci tohoto plánu nikdy nedošlo, resp. byly učiněny pouze jednotlivé malé kroky uvedeným směrem a legislativní aktivity v oblasti muzejnictví tak na čas usnuly.

Nově byly probuzeny opět počátkem 30. let v souvislosti s obnovením příprav památkového zákona. MŠANO jeho osnovu připravilo již v roce 1930, nebyla do ní však začleněna specifická muzejní problematika, hovořilo se zde pouze obecně o ochraně veřejných a soukromých sbírek. ${ }^{13}$ O rok později bylo na vedení Svazu zasláno upřesněné znění této osnovy s tím, aby se $\mathrm{k}$ němu vyjádřilo a navrhlo případné změny či doplňky. ${ }^{14}$ Muzejní rada Svazu se osnovou podrobně zabývala v červnu a červenci 1931, jak dosvědčuje i jednatelská zpráva, kterou na Valném shromáždění Svazu 21. června 1931 v Pardubicích podal jednatel

11 Národní muzeum spravoval historicky Spolek Národního muzea; po roce 1918 sílily snahy po jeho zestátnění.

12 Státní galerie vznikla zestátněním původní Obrazárny Společnosti vlasteneckých přátel umění.

13 ŠPÉT, Jiří. Muzea ve vývoji společnosti a národní kultury. Praha, 1983.

14 Dopis z Ministerstva školství a národní osvěty s touto žádostí a s př́ílohou obsahující návrh zákona o ochraně památek byl projednán na schůzi Muzejní rady 31. 5. 1931. Archiv Národního muzea, fond Svaz československých muzeí, kart. 55. Zápis ze schůze Muzejní rady Svazu československých muzeí ze dne 31. 5. 1931. 
Karel Guth. ${ }^{15}$ Dle jeho názoru (a patrně i dle názoru celé Muzejní rady) „je potřeba si prát, aby zákon byl přijat dle návrhu“. ${ }^{16}$ Předpokládal však, že během jeho schvalování nastanou obtíže vyvolané tím, že návrh významně zasahuje do oblasti soukromého práva. Po šesti dnech od data konání Valného shromáždění byly připomínky Svazu odeslány na MŠANO. Nakolik mohly být akceptovány, nevíme, nebot další projednávání návrhu zákona bylo pozastaveno. Zdůraznění role státních památkových úřadi̊ v návrhu zákona, třebaže posléze nepřijatého, mělo přesto v praxi pro muzejníky neblahé důsledky. Jako hlavnímu garantu památkové ochrany jim totiž byly předkládány i záležitosti vysloveně muzejního charakteru včetně žádostí o zřízení a schvalování nových muzeí. ${ }^{17}$ Svaz byl v těchto záležitostech často zcela opomenut. Proto se v letech 1932 a zejména 1933 prosadily ve vedení Svazu i mezi jeho členy znovu názory, že by bylo potřeba usilovat o skutečně samostatný muzejní zákon, popř. spojit své snahy s archiváři s cílem dosáhnout schválení společného zákona. Jako významný podklad pro jeho vytvoření měly sloužit již fungující zákony polské a mad’arské. Na Valné hromadě Svazu v květnu $1933^{18}$ bylo na návrh J. F. Svobody ${ }^{19}$

15 Karel Guth, 1883-1943, archeolog a historik umění, vysokoškolský pedagog, 1921-1941 přednosta historicko-archeologického oddělení Národního muzea, zakládající člen a dlouholetý funkcionář Svazu československých muzeí.

16 Archiv Národního muzea, fond Svaz československých muzeí, kart. 1. Zápis z Valné hromady Svazu československých muzeí ze dne 21. 6. 1931.

17 Stalo se tak např. u muzeí v Rosicích

a Kralicích, u nichž bylo do stanov navíc včleněno ustanovení, že se mají řídit památkovým zákonem (tř̌ebaže zatím neexistujícím). ŠPÉT, Jiří. Muzea ve vývoji společnosti a národní kultury. Praha, 1983, s. 134.

18 Valné shromáždění Svazu československých muzeí se konalo 25. 5. 1933

19 Josef František Svoboda, 1874-1946, vlastivědný a národopisný pracovník, historik a muzeolog, znalec Horácka, zakládající člen přijato usnesení, že bude od Státního památkového ústavu v Bratislavě opatřen překlad obou zákonů. Fridolín Macháček ${ }^{20}$ zde navíc patrně předložil i určité konkrétní zásady, jež by měl nový zákon obsahovat, neboť v zápise je zmíněn souhlas s jeho návrhy, „které se jeví jako nejvýhodnější“.

Žádost o překlad obou zákonů odešla do Bratislavy 9. listopadu téhož roku; odpověd', která do Prahy dorazila těsně po Vánocích, však patrně přední činitele Svazu příliš nepotěšila. Bratislavští památkáři v ní totiž uvedli, že polský zákon se týká jen Státního archeologického muzea, nikoliv muzejní sítě jako celku. Slíbili tedy, že se postarají alespoň o překlad a doručení zákona mad'arského. Co slíbili, to dodrželi, ${ }^{21}$ jenže v zásilce nebyl překlad nového mad’arského zákona o muzeích z roku 1929, který měli představitelé Svazu patrně na mysli, nýbrž pouze výtah z císařského nařízení o kompetenci hlavního státního dozorčího úřadu nad muzei a knihovnami z roku 1907. Dodání překladu onoho zmíněného novějšího zákona pak bylo přislíbeno slovenskými kolegy na Valném shromáždění Svazu, které se konalo 12 . května 1935 v Prostějově, a to ihned, jakmile bude hotový jeho překlad. Na témže shromáždění upozornil J. F. Svoboda delegáty, že archiváři zahájili přípravu nového archivního zákona a dal k úvaze, zda by se k nim muzejníci neměli připojit a vytvořit společný návrh. Jeho podnět však nenašel mezi kolegy patřičnou podporu, opět se začala

a dlouholetý funkcionář Svazu československých muzeí.

20 Fridolín Macháček, 1884-1954, muzejník a historik, městský archivář a sekretář Městského muzea v Plzni, zakládající člen a dlouholetý funkcionář Svazu československých muzeí, 1939-1952 jeho předseda.

21 Zásilka z Bratislavy dorazila do kanceláře Svazu československých muzeí 12. 9. 1934. Archiv Národního muzea, fond Svaz československých muzeí, kart. 1. Zápis ze schůze Muzejní rady ze dne 12. 5. 1935. prosazovat myšlenka samostatné zákonné normy. Nicméně o rok později, na schůzi Muzejní rady 5. srpna 1936, upozornil Václav Vojtíšek, který ve své osobě vhodně spojoval archiváře s muzejníkem, že klubem národně socialistických poslanců byl do parlamentu podán návrh zákona o archivnictví a že vlastní návrh chystají také MŠANO a Ministerstvo vnitra.

Ani tato poměrně slibně vyhlížející legislativní iniciativa však nebyla dovedena do zdárného konce a idea samostatného archivního (nebo společného muzejního a archivního) zákona byla po několika měsících zavržena. Politické poměry se totiž změnily a ve vládních kruzích byla oprášena myšlenka realizovat zákon o ochraně památek $s$ případným začleněním muzeí. Nestalo se tak však z vlastní iniciativy ministerstev, nýbrž spíše pod tlakem z několika stran, jak o tom svědčí také intervence, kterou v záležitosti památkového zákona uskutečnili na MŠANO zástupci Svazu Jaroslav Helfert $^{22}$ a Karel Guth. Svaz $\mathrm{v}$ této době usiloval především o to, aby do památkového zákona byla začleněna ochrana názvu „muzeum“. Zároveň pracoval na „předpokladech“ muzejního zákona, nebot i po případném vydání památkového zákona bude nutno regulovat nějakým způsobem muzejní práci. V červenci 1937 si vedení Svazu vyžádalo návrh památkového zákona k nahlédnutí a posléze vypracovalo i návrh textu paragrafu, jenž by jako součást památkového zákona alespoň částečně naznačil úlohu a význam muzeí v Československé republice. Návrh zněl takto: „Movité památky se chrání také $v$ museích a památkových síních. Musea jsou ústavy rízené podle statutu, vydaného Ministerstvem

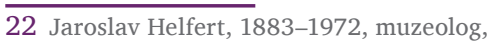
vysokoškolský pedagog, ředitel Městského muzea v Brně, zakládající člen a dlouholetý funkcionář Svazu československých muzeí. 
školství a národní osvěty a jsou pod jeho dozorem. Pamětní sín musí být pod dozorem některého muzea." Návrh byl poprvé předložen J. F. Svobodou na schůzi Muzejní rady 4. prosince $1938 .{ }^{23}$ Poslední zmínku o legislativních aktivitách Svazu v samostatné, i když územně okleštěné a politicky zglajchšaltované, Česko-slovenské republice, nacházíme v zápisu z jednání Muzejní rady ze dne 11. prosince $1938 .{ }^{24}$ Zástupce MŠANO Polák tehdy uvedl, že se připravuje široká reorganizace muzejnictví a navrhnul, aby Svaz sám vypracoval plán muzejní sítě a předložil jej ministerstvu. $\mathrm{V}$ následné diskusi podtrhl J. F. Svoboda úlohu vlastivědných muzeí a Gustav Skalský ${ }^{25}$ zdůraznil nutnost zahrnout do plánu i vnitřní organizaci muzejních institucí. Pro vyhotovení plánu byla schválena komise složená z členů předsednictva Svazu a státních inspektorů památek a rovněž z některých členů Muzejní rady. J. F. Svoboda poté již po několikáté podal návrh, aby do chystaného památkového zákona byl vložen odstavec o muzeích, předložený o týden dříve. Svoboda byl zřejmě i hlavním autorem návrhu muzejní sítě, jenž byl vypracován v průběhu roku 1938. Podle jeho představ měla být muzea rozdělena do 3 skupin - na vlastivědná, která se měla věnovat dokumentaci regionu (vzorem se mělo stát Národní muzeum), umělecko-průmyslová, jež měla vyvíjet sbírkotvornou činnost a dokumentační aktivity zejména $\mathrm{v}$ oblasti své působnosti, a specializovaná, která měla mít za úkol dokumentovat a prezentovat určitý obor nebo úsekové téma

23 ŠPÉT, Jiří. Muzea ve vývoji společnosti a národní kultury. Praha, 1983, s. 135.

24 Archiv Národního muzea, fond Svaz československých muzeí, kart. 55. Zápis ze schůze Muzejní rady ze dne 11. 12. 1938.

25 Gustav Skalský, 1891-1956, historik a numizmatik, vysokoškolský pedagog, ředitel Národního muzea, dlouholetý člen a funkcionář Svazu československých muzeí. (jednalo se např. o legionářská muzea). Všechny typy muzeí se měly řídi jednotným programem, který by zaručoval jejich vzájemnou návaznost. ${ }^{26}$

Pokud jde o územní rozdělení muzeí, držel se nový návrh původní koncepce Václava Adámka, přednesené na sjezdu muzejních spolků v Kutné Hoře v srpnu 1898. Na nejvyšším stupni měla stát ústřední muzea, zahrnující ve své činnosti celou šiŕi a všechny obory muzejní práce. O příčku níž by se ocitla krajová (krajská) muzea, jimž měla být vymezena oblast působnosti dle př́rodních, zeměpisných a lidopisných podmínek. Na třetím stupni by se ocitla muzea okresní a poslední skupinu by tvořily památní síně („místní sbírky“), jež by nemusely vytvořit sbírkový program a pouze by shromažd’ovaly památky místního významu. Dle zařazení do jednotlivých stupňů by muzea mohla být rovněž vybavena a strukturována. ${ }^{27}$ Téhož roku byl vyhotoven rovněž návrh programu muzeí. Muzejní instituce se měly zaměřit na dokumentování přírodních poměrů (geologického vývoje regionu i jeho současného př́rodního prostř̌edí), dále na období pravěku a starověku (archeologická oddělení) a na vývoj kraje v době historické (osada, její okolí a správa, obyvatelé, rodinný život, zaměstnání, hospodářský život, náboženský vývoj). Návrh muzejní sítě i programu byl rozeslán všem správcům muzeí a zároveň byl J. F. Svoboda pověřen, aby jeho účinnost prověřil v muzeu ve Strakonicích, což se

\footnotetext{
26 Text navrženého odstavce zněl: „Movité památky se chrání také $v$ muzeích a památkových síních. Muzea jsou ústavy řízené podle statutu vydaného Ministerstvem školství a národní osvěty a jsou pod jeho dozorem. Pamětní síň musí býti pod dozorem některého muzea." Archiv Národního muzea, fond Svaz československých muzeí, kart. 5. Návrh J. F. Svobody na znění odstavce o muzeích v novém zákoně o ochraně památek, nedat. (1938)

27 ŠPÉT, Jiří. Muzea ve vývoji společnosti a národní kultury. Praha, 1983, s. 136.
}

však vzhledem $\mathrm{k}$ vývoji politické situace neuskutečnilo. ${ }^{28}$

V období tzv. druhé republiky vypracovalo předsednictvo Svazu memorandum, $v$ němž zopakovalo svůj návrh na vytvoření muzejní sítě, tentokrát však už rozdělené jen do tří skupin - na muzea ústřední, krajová a místní. Memorandum obsahovalo rovněž požadavek zestátnit Národní muzeum a zorganizovat výchovu muzejních kádrů.. ${ }^{29} \mathrm{~V}$ lednu 1939 byla k předsedovi vlády Rudolfu Beranovi vyslána deputace, která jej informovala o současném stavu v oblasti muzejnictví a o potřebách celého oboru. Těsně před okupací českých zemí, 12. března 1939, se J. F. Svoboda vrátil k zákonu o památkách a předložil návrh, aby v tomto zákoně byl Svaz postaven na roveň památkovým úřadům a aby všechny muzejní spolky byly sdruženy v České obci sokolské a staly se jen jeho filiálkami, čehož se dalo dosáhnout prostřednictvím Ministerstva vnitra. Potřebu samostatného muzejního zákona opět zmínil na Valné hromadě Svazu v Praze dne 28. 9. 1939 ve své jednatelské zprávě Karel Guth s tím, že je nutno návrh zákona připravit v nejbližší době. ${ }^{30} \mathrm{Je}$ s podivem, že legislativní snahy Svazu zcela neustaly ani v obtížné době nacistické okupace $\mathrm{v}$ prostředí protektorátu. Na schůzi Muzejní rady 5. ř́jna 1940 byla sestavena přípravná komise ve složení Fridolín Macháček, Karel Guth, Jan Hofman, Jaroslav Helfert, Gustav Skalský a J. F. Svoboda, přičemž jako skutečný „spiritus agens“ v ní bezpochyby fungoval právě Macháček. V dopise J. F. Svobodovi $\mathrm{z}$ 8. prosince téhož roku totiž hovoří o tom, že v př́loze posílá návrh zákona a stejné sdělení

\footnotetext{
28 Tamtéž, s. 96.

29 Zejména se jednalo o Mnichovskou dohodu a předání pohraničních území Německu.

30 ŠPÉT, Jiří. Muzea ve vývoji společnosti a národní kultury. Praha, 1983, s. 139.
} 
obsahuje i jeho dopis Muzejní radě ze 7. ledna 1941, v němž zároveň vyzval ostatními členy rady $\mathrm{k}$ připomínkám a doplňkům. ${ }^{31}$

Konečný návrh byl předložen ministerstvu vnitra, do jehož kompetence nyní muzea spadala, avšak bez jakéhokoliv ohlasu. Další legislativní a prakticky veškeré aktivity přerušil nástup Reinharda Heydricha do funkce zastupujícího říšského protektora v září 1941, který přinesl výrazně přiškrcení veřejného života, a následná perzekuce $v$ rámci výjimečného stavu, který byl vyhlášen po atentátu na něj 27. května 1942. Teprve 19. října 1942 najdeme v zápise z Valné hromady Svazu informaci o tom, že MŠANO neakceptovalo návrh muzejního zákona připravený shora uvedenou komisí. ${ }^{32}$ Tím zatím iniciativa Svazu v zákonodárné oblasti skončila a z pochopitelných důvodů nebyla obnovena až do konce nacistické okupace.

\section{Podíl Svazu českých muzeí na legislativní činnosti v letech 1945-1959}

K oživení legislativních aktivit však došlo nedlouho po osvobození Československa. V předsednictvu Svazu se o zákonu jednalo již na prvním zasedání 12. 5. 1945, v Muzejní sekci ZNV pak 23. 5. $1945 .{ }^{33} \mathrm{Na}$ schůzi Muzejní rady Svazu 30. června 1945 Macháček ${ }^{34}$ referoval o svém původním návrhu samostatného muzejního zákona, resp. o osnově,

31 Archiv města Plzně, fond Fridolín Macháček, inv. č. 1678. Dopis Fridolína Macháčka J. F. Svobodovi ze dne 8. 12. 1940.

32 Archiv Národního muzea, fond Svaz československých muzeí, kart. 55. Zápis z Valné hromady Svazu českých muzeí ze dne 19. 10. 1942.

33 ŠPÉT, Jiří. Formování a rozvoj socialistického muzejnictví v ČSR (1945-1989). Praha: Národní muzeum, 1988, s. 38 (pozn. 49).

34 Macháček byl za nacistické okupace vězněn v koncentračním táboře. Na uvedené schůzi byl potvrzen ve funkci předsedy svazu. která byla vytvořena na konci okupace, našel však poměrně překvapivého oponenta $v$ osobě Jindřicha Čadíka, který doposud do debat ani do přípravy legislativní normy nezasahoval. Jeho námitky směřovaly proti ustanovení MŠANO za garanta oboru muzejnictví a rovněž proti členění muzeí obsaženého v návrhu. ${ }^{35}$ Dle Čadíka měla mít zvláštní postavení speciální, zejména uměleckoprůmyslová, muzea, která „potřebují samostatnou existenci“. Do diskuse se zapojil Gustav Skalský s tím, že o návrhu bude ještě hodně jednáno a že se zdaleka nejedná o jeho konečnou podobu. Macháček svůj návrh bránil, dle něj se netýkal specializace muzeí a navíc uměleckoprůmyslová muzea považoval již v této době za historická a lišící se pouze svým zaměřením. Prosazoval naopak nutnost vytvořit jednotnou organizaci. Posléze se členové rady alespoň dohodli, že návrh bude nyní rozeslán k posouzení jejím jednotlivým členům. ${ }^{36} \mathrm{~V}$ tomto okamžiku došlo k poněkud kuriózní situaci, když na vedení Svazu byl po čtrnácti letech od odeslání žádosti doručen text překladu mad’arského muzejního zákona z roku 1929. Svaz slovenských muzeí zatím zůstával samostatnou organizací, a proto byla jeho předsedovi Jánu Gerykovi $^{37} 1$. března 1946 odeslána stávající podoba návrhu muzejního zákona a rovněž i prováděcího nařízení vzešlá ze spolupráce Svazu a Muzejního Muzejní sekce při Zemském národním výboru v Praze. ${ }^{38}$ Jakou reakci

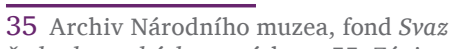
československých muzeí, kart. 55. Zápis ze schůze Muzejní Rady ze dne 30. 6. 1945.

36 Archiv Národního muzea, fond Svaz československých muzeí, kart. 55. Zápis ze schůze Muzejní rady ze dne 30. 6. 1945.

37 Ján Geryk, 1892-1978, muzeolog, etnolog, odborný pracovník a správce Slovenského národního muzea, předseda Svazu slovenských muzeí.

38 Muzejní sekce při kulturní komisi Zemského národního výboru v Praze byla založena již v květnu 1945. O rok později byla obdobná komise ustavena pod názvem Muzejní poradní sbor také návrh vyvolal, se z dochovaných dokumentů nedozvíme. Potřeba nutnosti přijetí muzejního zákona se však objevila v provolání, které Svaz připravil u př́ležitosti audience u prezidenta Edvarda Beneše v březnu 1946. V textu jsou uvedeny „nejbližší prostředky“ $\mathrm{k}$ tomu (tj. k rozvoji oboru) a mj. je zde řečeno: „Jest naprosto nutné vydati zákon o muzeích, a to $v$ době co nebližší, aby muzejní činnost získala zákonnou oporu, aby se stala i právně opravdu veřejným zájmem. “"39 Karel Tuček ${ }^{40}$ coby nově zvolený jednatel Svazu přednesl návrh textu muzejního zákona na první schůzi ministerské Muzejní rady, která se konala 17. 1. 1947.41 O návrhu se rozvinula široká a poněkud bezbřehá diskuse a přítomní členové rady se posléze dokázali shodnou pouze na jediném závěru: návrh bude ještě projednán užším výborem rady. $\mathrm{V}$ dalším období však příprava zákona zřejmě příliš nepokročila. Tento fakt potvrzuje i sdělení Františka Matouše ${ }^{42}$ na schůzi předsednictva Svazu 9. června 1948, že na ministerstvu se nic neděje a že vyhlídky na přijetí zákona jsou stejně mizivé

při Zemském národním výboru v Brně. Jejími členy byli od počátku za Svaz českých muzeí Karel Tuček, Gustav Skalský, Jiří Neústupný, Vladimír Denkstein, J. F. Svoboda a později i Fridolín Macháček. DOUŠA, Pavel. Organizace českého muzejnictví 1945-1989. Opava: Slezská univerzita v Opavě, Filozofická fakulta, 2005, s. 35. Dizertační práce.

39 Archiv města Plzně, fond Fridolín Macháček, inv. č. 1655. Návrh textu dopisu, rkp., nedat. (1946).

40 Karel Tuček, 1906-1990, mineralog, odborný pracovník Národního muzea, jednatele Svazu českých muzeí, úředník Ministerstva školství, věd a umění.

41 Muzejní rada při Ministerstvu školství a osvěty byla zřízena vládním výnosem vydaným 22. 11. 1945. Její ustavující (a zároveň jediné) zasedání se však konalo teprve 17. 1. 1947 za předsednictví ministra Jaroslava Stránského. Svaz v ní zastupovali Jaroslav Helfert, Karel Herain, Gustav Skalský a Karel Tuček. DOUŠA, Pavel. Organizace českého muzejnictví 1945-1989. Opava: Slezská univerzita v Opavě, Filozofická fakulta, 2005, s. 37. Dizertační práce.

42 František Matouš, 1895-1969, historik umění, ředitel Jihočeského muzea v Českých Budějovicích, od 1947, přednosta oddělení pro muzea a galerie na Ministerstvu školství a národní osvěty, resp. na Ministerstvu kultury. 
jako před únorovými událostmi. Na Valné hromadě Svazu v květnu téhož roku tak bylo možno pouze konstatovat, že oboru muzejnictví stále chybí právní základ a z toho vyplývají mnohé další potíže.

\section{Další podnět $\mathrm{k}$ legislativním} aktivitám prrišel tentokrát „zdola“. Na krajské konferenci muzejních pracovníků v Liberci, která se konala 20. listopadu 1948, byla přijata rezoluce s požadavkem urychleně vypracovat muzejní a archivní zákon, na jehož přípravě by se měla podílet i mimopražská muzea a archivy. Liberečtí muzejníci zároveň doporučovali zachovat muzejní spolky a jejich třetinové zastoupení ve správních radách muzeí, zrrídit státní muzejní školu, zabránit vývozu kulturních památek, knih a archiválií do zahraničí a převést prodej movitého kulturního dědictví z Fondu národní obnovy na nedávno vytvořené Ministerstvo školství, vědy a umění. Jelikož není muzejní zákon připraven ani v návrhu, ${ }^{43}$ mohou př́tomní muzejní pracovníci vyjádřit pouze přání, aby obsahoval jisté zásady. ${ }^{44}$

\section{Vzápětí - 11. prosince 1948 - byl} „svazový“ návrh zákona rozeslán jednotlivým muzeím s tím, aby podala své připomínky do 15 . ledna 1949. Tohoto dne totiž zasedala v Pieštanech Muzejní rada spolu se zástupci vedení Svazu slovenských muzeí. Jednající se zabývali

43 Muzejníci libereckého kraje v té době ještě neznali návrh vypracovaný vedením Svazu českých muzeí.

44 Dle rezoluce by zákon měl zahrnovat účel a činnost muzeí a připustit pouze jejich veřejnoprávní vlastnictví, ochránit název „muzeum“, nařídit povinnou existenci muzejních spolků a jejich třetinové zastoupení v kuratoriích; spolky by měly zajištovat vědeckou práci

v muzeích a péči o sbírky; zákon by měl dále určit složení kuratorií ze zástupců korporací, vedení muzea a odborníků a rovněž stanovit povinnost zřídit vědeckou knihovnu; v jednotlivých krajích by měly být zřízeny krajské muzejní rady (o 9 členech), které budou vykonávat jak odborný, tak i administrativní dozor. Archiv Národního muzea, fond Svaz československých muzeí, kart. 11. Rezoluce z krajské konference muzejních pracovníků Libereckého kraje ze dne 20. 11. 1948. připomínkami k českému návrhu, které byly zaslány od několika desítek muzeí, a to jak státních (např. od Národního muzea, Uměleckoprůmyslového muzea, Zemských muzeí v Brně a v Opavě) či muzeí střední velikosti (Teplice, České Budějovice, Poděbrady, obě plzeňská muzea), tak i malých místních a spolkových (Bělá pod Bezdězem, Bojkovice, Chlumec nad Cidlinou, Hořice, Protivín). Týkaly se zejména sladění muzejní sítě s připravovanými změnami státní správy a samosprávy, ${ }^{45}$ realizace odborných muzejních kurzů pro pracovníky malých muzeí, předání soukromých, školních, spolkových a dalších sbírek nejbližšímu okresnímu muzeu, majetkového a předkupního práva muzeí na významné památky, zřízení odborných pracovišt ${ }^{46}$ v jednotlivých krajích, upřesnění poměru mezi muzei a jejich "matečními organizacemi“ státem a národními výbory, činnosti muzejních kuratorií a případného povinného sloučení malých muzeí do okresních. ${ }^{47}$ Většinový požadavek se také týkal důležitosti role muzejních spolků a na nezbytné úpravy hmotných (platových) poměrů muzejních zaměstnanců. Některé zaslané náměty zahrnovaly i publikační právo muzeí v souvislosti s připravovaným nakladatelským zákonem. Na schůzi Muzejní rady 6. února téhož roku bylo přečteno sdělení Svazu slovenských muzeí, v němž bylo konstatováno, že návrh českého svazu nebere na Slovensko zřetel, a proto hodlá vypracovat a poté předložit Slovenské národní radě vlastní návrh. Oba paralelní návrhy by však měly mít stejné nebo alespoň obdobné hlavní

\footnotetext{
45 V roce 1949 proběhla zásadní reforma státní správy i samosprávy, která přinesla zrušení zemí, navýšení počtu krajů i politických okresů a zrušení soudních okresů.

46 Odborná pracoviště se měla zabývat konzervací, kopírováním, fotografováním a odborným určováním sbírek.
}

47 Při zachování významných městských muzeí. zásady. V následujícím měsíci, konkrétně 25. března 1949, pak zasedlo předsednictvo Svazu, aby projednalo upravený Macháčkův návrh textu zákona, $v$ němž již byly zahrnuty některé došlé připomínky. ${ }^{48} \mathrm{O}$ měsíc později ještě došlo $\mathrm{k}$ dalšímu menšímu doplnění o návrhy Jiřího Neustupného. ${ }^{49}$

Obě legislativní normy byly podpořeny na Valné hromadě SČM ve Znojmě 15. května 1949. Macháček poté pracoval ještě na textu prováděcího nařízení, jak o tom svědčí žádost o urychlení jeho práce obsažená v dopisu, který mu Tuček a Skalský odeslali 30. 5. 1949. ${ }^{50}$ Macháček však odpověděl, že svůj původní návrh již odevzdal Tučkovi na Valné hromadě a nemá nic podstatného k jeho doplnění. ${ }^{51}$ Stávající podoba návrhu zákona i prováděcího nařízení pak byla schválena na zasedání předsednictva Svazu 10. června 1949. Macháček se k nim měl ještě jednou vyjádřit a případně je upravit podle připomínek zaslaných na vedení Svazu jednotlivými muzei, aby tak vznikla definitivní podoba textů, jež měla

48 Pozměněn byl § 4: Aby bylo možno pečovati o musejní materiál rovnoměrně na celém území státu, dělí se musea po stránce A) obsahové na: 1) všeobecná, 2) odborná; B) rozsahové na: 1) celostátní, 2) oblastní (Brno, Opava, Bratislava), 3) krajová, 4) obvodová či okrsková. § 5 a 6 byly vyškrtnuty. Archiv Národního muzea, fond Svaz československých muzeí, kart. 6. Zápis ze schůze předsednictva Svazu českých muzeí ze dne 25. 3. 1949.

49 Jiří Neustupný, 1905-1981, archeolog a muzeolog, vysokoškolský pedagog, odborný pracovník Národního muzea, ve 40. a 50. letech funkcionář Svazu českých muzeí. Začlenění Neústupného návrhů znamenalo rozšíření subjektů, jichž se zákon týkal, na „muzea a galerie" v celém textu zákona a nahrazení slov „se souhlasem“ slovy „po doporučení“ v § 6. Archiv Národního muzea, fond Svaz československých muzeí, kart. 6. Zápis z Valné hromady Svazu českých muzeí ze dne 15. 5. 1949.

50 Archiv města Plzně, fond Fridolín

Macháček, inv. č. 1655. Dopis Karla Tučka a Gustava Skalského Fridolínu Macháčkovi ze dne 30. 5. 1949.

51 Archiv města Plzně, tamtéž. Dopis Fridolína Macháčka Karlu Tučkovi ze dne 8. 6. 1949. 
být prodebatována na zasedání předsednictva Svazu 21. 6. 1949. ${ }^{52}$

Zda se tak skutečně stalo, nelze z archivních pramenů zjistit. Víme však s určitostí, že 16. července 1949 odeslali Karel Tuček a Gustav Skalský návrh zákona o muzeích a galeriích, jak byl nyní nazván, slovenským partnerům. ${ }^{53}$ Návrh byl velice stručný, v deseti paragrafech se zabýval definicí muzeí a jejich činnosti, orgánem, který vykonává nad muzei dozor (mělo jim být Ministerstvo školství, věd a umění), ochranou názvu „muzeum“, rozdělením muzeí po stránce obsahové (všeobecná a speciální), resp. územní (celostátní, oblastní, krajová a obvodová čili okrsková), odborností pracovníků (až na zvláštní výjimky se mělo jednat o vysokoškolsky vzdělané odborníky), financováním a poradními orgány (Státní a krajskou muzejní radou). Členství ve Svazu mělo být dle návrhu povinné. Text zřetelně vycházel z předcházejících návrhů a poválečným podmínkám, resp. prostředí po nástupu komunistické moci se přizpơsobil jen nepatrně. ${ }^{54}$ Na zasedání předsednictva Svazu, které jednalo 4. 10. 1949, byl Macháček znovu dotázán, zda a nakolik pokročil s redakcí prováděcího nařízení. Z jeho neurčité odpovědi vyplynulo, že se této věci zřejmě příliš nevěnoval. Plánovaná schůzka s vedením Svazu slovenských muzeí, která se měla touto záležitostí zabývat, se tak neuskutečnila. V dopise z 27. 10. 1949 nicméně Macháček

\footnotetext{
52 Zápis z uvedené schůze se nedochoval. V pozvánce, kterou Tuček a Skalský poslali Macháčkovi, je však uvedeno, že na této schůzi bude návrh zákona projednáván. Archiv města Plzně, fond Fridolín Macháček, inv. č. 1655. Pozvánka na schůzi předsednictva Svazu dne 10. 6. 1949.

53 Archiv Národního muzea, fond Svaz československých muzeí, kart. 6. Dopis Fridolín Macháčka a Gustava Skalského předsednictvu Svazu slovenských muzeí ze dne 16. 7. 1949. Text návrhu je publikován jako Příloha 1

54 Státní rada - zde míněna zřejmě Muzejní rada při Ministerstvu školství a osvěty.
}

Tučkovi sděluje, že „Charvát asi dá projednat celou řadu ochranářských zákonů najednou (ochrana památek, archivní, muzejní)" a že tedy bude lepší předložit mu „svazový“ návrh zákona i prováděcího nařízení později. ${ }^{55}$

Ministerstvo školství a osvěty chce totiž kvůli zákonu svolat Státní radu, ${ }^{56}$ což se zatím jeví jako dostatečný krok k realizaci nové legislativní normy. Během dalšího půl roku se však situace výrazně změnila. Na schůzi Muzejní rady 12. března 1950 totiž referoval František Matouš o jednání na meziministerské poradě, na níž byl projednáván zákon na ochranu památek se zvláštním odstavcem věnovaným muzeím a archivům. $\mathrm{V}$ podstatě se tak opakovala situace z počátku 30. let, i když ve zcela jiných politických podmínkách. Návrh památkového zákona (zákona o kulturních památkách) měl již 15. března obdržet kabinet Ministerstva školství, věd a umění, jenž jej měl vzápětí předložit vládě. V červnu se očekávalo jeho schválení Národním shromážděním. Tuto skutečnost sdělilo předsednictvo Svazu 16. března také svým slovenským partnerům a po týdnu ji potvrdilo v dalším dopise s tím, že zákon je zařazen v legislativním plánu na rok 1950. Bližší úpravu onoho „muzejního odstavce“ má přinést speciální vládní nařízení. Na Slovensku se předpokládá postup dle vlastních

\footnotetext{
55 Jaroslav Charvát, 1904-1988, historik a archivář, autor učebnic, editor spisů Františka Palackého, pracovník Ministerstva školství a osvěty.

56 V dopise bylo uvedeno: „Muzejní pracovníci uvážili, že potěšitelný rozvoj muzejní práce $v$ posledních letech nezbytně vyžaduje také právního zabezpečení sbírek, kulturních dokladi̊ a památek, které jsou nepopiratelnou důležitou složkou našeho budovatelského programu, třídního uvědomění a oporou na naší cestě $k$ socialismu. Dủležité úkoly lidovýchovné, které mají muzea plnit ve výstavních sbírkách, musí být opreny o náležitý a promyšlený muzejní zákon." Archiv Národního muzea, fond Svaz československých muzeí, kart. 11. Sdělení předsednictva Svazu českých muzeí pro Ministerstvo školství, umění a vědy ze dne 16. 6. 1950.
}

potřeb. Schvalovací proces ve vládě se však zřejmě výrazně opožd’oval, nebot' na Valné hromadě Svazu v Chebu 4. června 1950 byl do závěrečného usnesení začleněn požadavek urychleného vydání památkového zákona, o čemž bylo v dopise z 16. června uvědoměno i ministerstvo. ${ }^{57}$

Společná porada vedení Svazu českých muzeí a Svazu slovenských muzeí, která proběhla 1 . prosince 1950 v Bratislavě, pak přinesla dohodu o tom, že obě sdružení společně požádají ministerstvo o svolání příslušných činitelů $\mathrm{k}$ poradě o formulaci textu prováděcího nařízení k zákonu o kulturních památkách, konkrétně k § 6, který se měl týkat muzeí. Návrh zákona již v tomto okamžiku měli v rukou i poslanci Národního shromáždění. Naděje na přijetí zákona trvala ještě nějakou dobu. O rok později však již bylo jasné, že práce na zákoně byly pozastaveny, což bylo konstatováno na Valném shromáždění Svazu v Kutné Hoře. ${ }^{58}$ Ani posun termínu projednání zákona, původně na druhé pololetí roku 1950 již neplatil, vše bylo odloženo na druhou pětiletku.

Stejně jako již několikrát v minulosti se tak znovu vynořila myšlenka připravit samostatný muzejní zákon. Urychlené dokončení jeho návrhu a brzké vyhlášení požadovala např. porada zástupců muzeí Brněnského kraje, jež se konala 7. a 8. dubna 1952. ${ }^{59}$ Bezprostřední reakci vedení Svazu neznáme, resp. není v dochovaných dokumentech podchycená. Zřejmě však nebyla

\footnotetext{
57 Toto sdělení zaznělo v jednatelské zprávě, kterou přednesl Karel Tuček.

58 Archiv Národního muzea, fond Svaz československých muzeí, kart. 5. Usneseni z porady zástupců muzeí Brněnského kraje ze dne 8. 4. 1952.

59 Archiv Národního muzea, fond Svaz československých muzeí, kart. 2. Jednatelská zpráva přednesená na Valné hromadě Svazu českých muzeí v Českých Budějovicích, nedat. (1952).
} 
př́liš pozitivní, pod vlivem politických událostí první poloviny 50. let si předsednictvo netroufalo vystupovat v této záležitosti příliš aktivně. Svědčí o tom i doporučení, obsažené v jednatelské zprávě z Valné hromady Svazu v Českých Budějovicích ve stejném roce: muzejní spolky se mohou na základě nově vydaného zákona č. 68/51 Sb. o dobrovolných organizacích a shromážděních začlenit do jiných masových organizací. ${ }^{60}$ Spolkový majetek včetně sbírek by tak přešel do veřejného vlastnictví. Nicméně Karel Tuček, nyní už z titulu vedoucího muzejního oddělení a člena vládní muzejní komise při ministerstvu školství a osvěty, ${ }^{61}$ ještě 17. 10. 1953 Macháčka v dopise informoval, že návrh samostatného muzejního zákona má být vládou schválen do konce roku; hrubý náčrt jeho osnovy je již hotov a nyní jej projednávají legislativci. Poté bude rozeslán muzeím s týdenní lhůtou k připomínkování. Tuček slíbil, že jej odešle i Macháčkovi. ${ }^{62} \mathrm{Z}$ tohoto plánu však zřejmě sešlo, nebot’ v následujících čtyřech letech nenajdeme v materiálech Svazu o jakémkoliv legislativním předpisu, který by se týkal muzeí, ani zmínky. Teprve 16. července 1957 odeslali ministru školství a kultury Františkovi Kahudovi ${ }^{63}$ dopis s memorandem vzešlým ze sjezdu

60 Vládní muzejní komise byla zřízena usnesením předsednictva vlády ze dne 27. 4. 1953 a sestávala z muzejní a památkové sekce. Do jejího vedení byl dosazen náměstek ministra Zdeněk Buříval. Již v únoru 1955 však byla zrušena. DOUŠA, Pavel. Organizace českého muzejnictví 1945-1989. Opava: Slezská univerzita v Opavě, Filozofická fakulta, 2005, s. 90. Dizertační práce.

61 Archiv města Plzně, fond Fridolín Macháček, inv. č. 1655. Dopis Karla Tučka Fridolínu Macháčkovi ze dne 17. 10. 1953.

62 Do roku 1948 spadala muzea pod Ministerstvo školství a osvěty, poté přešla pod nově zřízené Ministerstvo školství, věd a umění, jež bylo v roce 1953 rozděleno na Ministerstvo školství, Ministerstvo vysokých škol a Ministerstvo

kultury; tato ministerstva byla v roce 1956 znovu sloučena do Ministerstva školství a kultury.

63 František Kahuda, 1911-1987, fyzik, vysokoškolský pedagog, politik, od 1954 ministr kultury, 1956-1964 ministr školství a kultury.
Svazu v Teplicích předseda Svazu Vladimír Denkstein ${ }^{64}$ a jednatel Karel Tuček. Zdůraznili přitom, že návrh nevyžaduje žádná finanční opatření, tedy zvýšené náklady, a v podstatě pouze legalizuje současný stav. ${ }^{65}$ Text tohoto návrhu však nebyl bez výhrad přijímán všemi muzejními pracovníky ani obory. Předseda Komise pro vlastivědná muzea Zdeněk Strniska ${ }^{66}$ shrnul ve svém dopise Muzejní radě ze 4. dubna 1958 řadu připomínek, které se týkaly zejména archeologických výzkumů a sbírek, a doporučoval začlenit archeologickou problematiku spíše do památkového zákona. Jednání na Ministerstvu školství a kultury však nepokračovala tempem, jež by muzejníky uspokojilo. Na společném zasedání vedení Svazu českých muzeí a Svazu slovenských muzeí bylo naopak konstatováno, že vydání zákona bylo zatím bezvýsledně na ministerstvu urgováno, pouze zdlouhavě diskutováno v muzejní komisi ministra Kahudy a rovněž zmíněno jako požadavek $\mathrm{v}$ dopise na ÚV KSČ. Zpracování zákona přesto nadále zůstalo součástí legislativního plánu ministerstva na rok 1958.

Na zasedání muzejní rady Svazu slovenských muzeí v Prešově a Sabinově, uskutečněném 4. a 5. března 1959 mohl Václav Pubal ${ }^{67}$ jako zástupce vedení vazu českých muzeí konečně podat informaci, že osnova zákona o muzeích a galeriích je již dohotovena, že samotný zákon vyjde v červnu

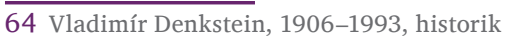
umění a muzeolog, 1956-1970 ředitel Národního muzea, 1952-1960 předseda Svazu českých muzeí. 65 Archiv Národního muzea, fond Svaz československých muzeí, kart. 11. Dopis Vladimíra Denksteina a Karla Tučka ministru školství a kultury Františku Kahudovi ze dne 16. 7. 1957.

66 Zdeněk Strniska, 1925-2009, muzejník, sociolog, 1953-1960 ředitel Krajského muzea v Gottwaldově, 1968 emigroval do Francie.

67 Václav Pubal, 1913-1992, knihovník, muzeolog, náměstek ředitele Národního muzea, 1956-1980 ředitel Ústředního muzeologického kabinetu. a že ve stejné době budou připravena i veškerá prováděcí nařízení. Přípravu zákona měla na starosti komise jmenovaná Ministerstvem školství a kultury a Ústřední muzejní radou ${ }^{68}$ a vedl ji ředitel Národní galerie Vladimír Novotný, ${ }^{69}$ zatímco pověřeným referentem na ministerstvu byl Josef Beneš. ${ }^{70}$ Jak všichni víme, po dlouhých letech nekonečných jednání, nevyslyšených žádostí a nesplněných slibů se tak skutečně stalo, přičemž konečnou podobu dal novému zákonu legislativní pracovník ministerstva V. Houska.

Zákon o muzeích a galeriích č. 54/1959 Sb., jenž - včetně několika aktualizací - zůstal v platnosti až do roku 2000, byl posléze vydán 9. července 1959. $\mathrm{V}$ roce 1961 a poté znovu v roce 1984 byl pouze doplněn směrnicí Ministerstva školství a kultury, resp. Ministerstva kultury, která stanovila, jak má vypadat správa, evidence a ochrana muzejních sbírek. Směrnice samozřejmě neměla váhu legislativní normy, byla a zůstala pouhým doporučením, nicméně muzea se jí povětšinou řídila. Na její přípravě se podílela Ústřední muzejní rada ${ }^{71}$ spolu s Ústředním muzeologickým kabinetem.
68 Ústřední muzejní rada byla ustanovena při Ministerstvu školství a kultury 28. 3. 1956. Měla 25 členů a v jejím čele stál Karel Tuček. První schůze se však konala až 1. 12. 1958. DOUŠA, Pavel. Organizace českého muzejnictví 1945-1989. Opava: Slezská univerzita v Opavě, Filozofická fakulta, 2005, s. 91. Dizertační práce.

69 Vladimír Novotný, 1901-1977, historik umění, 1945-1960 ředitel Národní galerie.

70 Josef Beneš, 1917-2005, pedagog, etnolog a muzeolog, od 1956 referent pro muzea na Ministerstvu školství a kultury, později odborný pracovník Ústředního muzeologického kabinetu.

71 Ústřední muzejní rada fungovala se dvěma přestávkami až do roku 1990. DOUŠA, Pavel. Organizace českého muzejnictví 1945-1989. Opava: Slezská univerzita v Opavě, Filozofická fakulta, 2005, s. 128. Dizertační práce. 
Asociace muzeí a galerií Čr a příprava nového muzejního zákona

V devadesátých letech bylo podniknuto několik pokusů, jak zákon č. 54/1959, který již nevyhovoval novým společenským a politickým poměrům po roce 1989, novelizovat či zcela zrušit a nahradit jej novým, kvalitnějším legislativním předpisem. Zde je nutno zmínit především několik verzí návrhu zákona o muzeích (a galeriích), popř. o veřejně prospěšných institucích v kultuře, z nichž však žádná nedospěla dále než do projednání legislativní radou vlády či do prvního čtení v parlamentu. A to také $\mathrm{z}$ toho důvodu, že mnohem větší důležitosti nabyla v období, kdy byly „otevřeny“ státní hranice, ochrana muzejních sbírek před jejich zcizením a neregulovaným vývozem. Na tuto skutečnost reagoval nejprve zákon

č. 71/1994 Sb. o vývozu movitého kulturního dědictví a posléze také po dlouhých diskusích připravený a schválený zákon č. 122/2000 Sb. o ochraně sbírek muzejní povahy, doplněný ve stejném roce prováděcí vyhláškou č. 275/2000 Sb. Poněkud nesystematicky byl tento zákon v roce 2004 novelizován zákonem č. 483/2004 Sb., když do něj byly začleněny některé standardy veřejných služeb $\mathrm{v}$ oblasti muzejnictví, zejména standard územní, časové, ekonomické a fyzické dostupnosti. Teprve $\mathrm{v}$ této situaci bylo možno vrátit se $\mathrm{k}$ diskusi a případně $\mathrm{i} \mathrm{k}$ prrípravě nového „oborového“ zákona, jenž by legislativně podchytil existenci a veškeré činnosti muzeí a galerií. Na základě zahraničních zkušenostî ${ }^{72}$ se začaly nejprve zkoumat možnosti ustavení či spíše uzákonění sítě funkčních muzeí, která plní hlavní zásady

72 Registrační systém byl již několik let úspěšně uplatňován např. ve Velké Británii, Nizozemsku či Rakousku, v centralizované podobě funguje také na Slovensku. muzejní činnosti. Začalo se hovořit o jejich registraci, popr. akreditaci. K registraci muzeí se jako první v roce 2005 vyjádřil v poměrně stručném materiálu tehdejší vedoucí oddělení muzeí a galerií v rámci odboru pro péči o movité kulturní dědictví Ministerstva kultury Jiří Žalman. Dle jeho názoru by mohlo zavedení registru přispět ke zvýšení důvěryhodnosti muzeí a ke zkvalitnění jejich činnosti. Zařazení do registru by zároveň mohlo znamenat pro muzea snadnější přístup k dotacím ze státního rozpočtu. Základním předpokladem pro vytvoření registru musí být sjednocení etických a profesních standardů na základě etického kodexu a aplikované muzeologie. Žalmanova představa o způsobu hodnocení již tehdy v podstatě odpovídala současnému pojetí a vycházela především z práce Dagmar Fialové. ${ }^{73}$ Muzea by vyplněním dotazníku s povinnými př́lohami zhodnotila sama svou činnost, přičemž pověření pracovníci ministerstva by poté mohli relevantnost informací obsažených v dotazníku ověřit na místě. Registrace by měla být povinná pro všechna muzea řídící se zákonem č. 122/2000 Sb. a měla by být uvedena do praxe na základě doplnění tohoto zákona několika body (viz níže). Registračním centrem bude bud' pověřený, nebo nově vytvořený státní orgán, mohla by se jím však stát i pověřená, již existující instituce (i nestátní). Žalman předpokládal, že by mohlo jít o vícestupňový proces, touto otázkou se však blíže nezabýval.

Doplnění zákona č. 122/2000 Sb. by mělo obsahovat především tyto zásady: a) sbírka zapsaná v Centrální evidenci sbírek (CES) je spravována institucí, která musí doložit, že se jedná o skutečné

\footnotetext{
73 FIALOVÁ, Dagmar. Profesní a etické standardy a výkonnostní ukazatele muzejní práce. Národní systém muzeí jako nástroj udržení společné odborné a etické základny muzeí $v$ ČR. Praha: Asociace muzeí a galerií ČR, 2003.
}

muzeum (tj. ve smyslu zákona).

Pouze $\mathrm{v}$ tom prrípadě bude

Ministerstvem kultury registrováno a tato skutečnost bude uvedena v zápisu do CES; b) zároveň se tímto správním úkonem muzeum stane poskytovatelem veřejných služeb (bude mu přidělena jakási „chráněná značka“); c) do registru však budou moci být zařazena i muzea, která nejsou poskytovateli veřejných služeb, tj. zřizována jinými typy zřizovatelů, než jsou uvedeni v zákoně č. 122/2000 Sb.; d) dotazník pro muzea, která budou usilovat o zařazení do registru, vypracuje Ministerstvo kultury ve spolupráci s odbornou veřejností; e) vyhodnocení dotazníku bude provádět opět Ministerstvo kultury nebo jím pověřená příspěvková organizace.

Bez bližšího vysvětlení pak Žalman uvádí tzv. minimální standardy činnosti muzeí, které by měly zřejmě představovat základní předpoklady pro zařazení muzeí do registru.

Následně byl z Ministerstva kultury na Asociaci muzeí a galerií ČR zaslán pracovní návrh hlavních zásad budoucího systému. ${ }^{74}$ Muzea by na základě hodnocení byla registrována či akreditována jako a) národní; b) nadregionálního významu; c) místního významu; d) místní památníky. Mohla by pritom usilovat o postup do vyšší kategorie; jakou cestou, to však v návrhu nebylo zmíněno. Ministerstvo předpokládalo, že v prvním pořadí budou registrována všechna muzea zřizovaná státem a kraji, dále přibližně $2 / 3$ muzeí zřizovaných obcemi a snad i několik dalších. Později by i jiná muzea mohla o registraci/akreditaci požádat a usilovat. K zavedení systému by patrně stačila novela zákona č. 122/2000 Sb. s názvem

\footnotetext{
74 Návrh byl zaslán jako př́loha dopisu. Archiv Asociace muzeí a galerií ČR, fond Legislativa kultura. Dopis z Odboru muzeí a galerií Ministerstva kultury ze dne 13. 9. 2005.
} 
„...o registraci muzeí a o změně některých dalšich zákonů“. Novela by měla být založena na úpravě registrace muzeí, na vymezení základních okruhů požadovaných standardů a měla by obsahovat také zmocnění Ministerstva kultury $\mathrm{k}$ úpravě standardů prováděcí vyhláškou.

AMG v prvním i v první polovině druhého desetiletí 21. století několikrát vyzvala Ministerstvo kultury, aby ve spolupráci s ní, ale také s Radou galerií ČR (RG), s Českým výborem ICOM (ČV ICOM) a popř. i s dalšími zástupci odborné veřejnosti zahájilo přípravu systému registrace (a akreditace) muzeí. Představy AMG o jeho podobě zformuloval V roce 2011 František Šebek ve stati Muzea a galerie. ${ }^{75}$ Vycházel přitom ze základního standardu muzejní práce $\mathrm{v}$ rámci Mezinárodního etického kodexu muzeí, který byl přijat na 15. Valném shromáždění ICOM v Buenos Aires v roce 1986 a aktualizován o patnáct let později na 20. Valném shromáždění ICOM v Barceloně. Z něj konec konců vychází i definice muzea obsažená v zákoně č. 122/2000 Sb. o ochraně sbírek muzejní povahy. Šebek ve své úvaze připomněl, že slovo (pojem) „muzeum“ nepožívá žádné právní ochrany a mohou jej tedy užívat instituce různého typu, často pouze jako marketingový a propagační prostředek. Existují na druhé straně instituce, jež slovo „muzeum“ v názvu nemají, avšak z hlediska své činnosti muzei bezpochyby jsou (památníky různého typu, galerie, skanzeny atd.). Česká republika by se při vytváření registru muzeí mohla inspirovat v zemích, kde již registrační systém funguje jako veřejně přístupný seznam a kde muzea zanesená v registru nesou

75 ŠEBEK, František. Muzea a galerie. Nedat.; Archiv Asociace muzeí a galerií CR, fond Legislativa - kultura. zvláštní označení (např. piktogram) jako prestižní symbol své úrovně.

V dané chvíli existují o muzeích jen omezené informace založené na zápisu v CES podle zákona č. 122/2000 Sb. Takto je navíc podchycena jen část muzeí tj. zřizovaných státem, požádali o zápis do CES nebo pravidelně vyplňují statistický výkaz V-Kult 14.01 MK. Tyto informace rozhodně nedostačují k tomu, aby byly vytvořeny ambivalentní podklady pro systém registrace. $\mathrm{K}$ tomu naopak velice napomůže projekt benchmarkingu muzeí, který od roku 2009, zatím v podobě pilotního projektu, realizuje Národní informační a poradenské středisko pro kulturu (NIPOS) ve spolupráci s AMG a jenž je založen na srovnávání výkonnostních indikátorů v rámci ČR, ale také regionů nebo muzeí obdobné velikosti či zaměření.

\section{Dle Šebka bude k vypracování} systému evaluace muzeí nezbytné vytvořit registrační systém, jenž bude nějakým způsobem legislativně ukotvený. Bude rovněž nutné připravit soustavu výkonnostních a etických standardi̊, na jejichž základě budou muzea do registru zařazována, a to na základě konsensu různých typů a oborů muzejních institucí. Akreditační systém by pak měl tvořit nadstavbu nad registrací jako - patrně - několikastupňový ukazatel kvality v jednotlivých, porovnatelných muzejních kategoriích. Šebek měl již k dispozici obsáhlý materiál Anny Komárkové, ${ }^{76}$ který popisoval jednotlivé registrační systémy v zahraničí, navíc však přinesl i jejich vzájemné srovnání a zdůraznil jejich shody i rozdíly. Materiál zčásti vycházel z britské

76 KOMÁRKOVÁ, Anna. Registrační systém muzeí. Zjištění používaných metod evaluace $v$ zahraničí. Nedat. (2010); Archiv Asociace muzeí a galerií ČR, fond Legislativa - kultura. analýzy z roku $2002^{77}$ s důrazem na přínosy i určitá negativa, jež nové systémy přinesly. Rozsáhlejší pasáže jsou zde věnovány registračním systémům, jež by mohly být inspirací i pro české muzejnictví ve Velké Británii, Nizozemsku, Rakousku a na Slovensku. Z textu Anny Komárkové vychází také následně publikovaný materiál NIPOS, který je ve své druhé části rovněž zaměřen na problematiku registrace a akreditace muzeí. ${ }^{78}$

V letech 2012-2013 realizovala RG spolu s Metodickým centrem pro výtvarné umění při Národní galerii projekt Standardy práce se sbírkami $v$ galeriích, na nějž $\mathrm{v}$ roce 2014 navázal materiál Minimální standardy mobility sbírek. V rámci projektu byl vypracován podrobný soupis standardů, z nichž by měly galerie při své činnosti vycházet. ${ }^{79}$ Pro muzea byly oba materiály a v nich uvedené standardy vhodné a přijatelné jen částečně, nicméně i dnes, po šesti letech, je potřeba ocenit aktivitu a cílevědomost obou subjektů, jež se na realizaci projekt podílely.

Vytvoření systému registrace/ akreditace muzeí se jako jeden z významných bodů (odstavec 3.2.2.) objevilo v Koncepci rozvoje muzejnictví na léta 2015-2020, kterou v roce 2015 sestavil Odbor muzeí a galerií Ministerstva kultury (OMG). V textu bylo uvedeno, že systém bude připravován ve spolupráci s odbornými sdruženími,

77 MASON, Timothy a Jane WEEKS. From Australia to Zanzibar. Museums Standard Schemes Overseas. A research project for ressource. London: The Council for Museums nad Libraries, 2002.

78 Jak muzejní akreditační program pracuje, včetně práv a povinností registrovaných a akreditovaných muzeí. Praha: NIPOS, nedat.; Archiv Asociace muzeí a galerií ČR, fond Legislativa - kultura.

79 Jako základní okruhy byly vymezeny: standardy muzejní budovy; standardy péče o sbírky; standardy práce s veřejností; standardy uživatelského (návštěvnického) komfortu, včetně fyzické dostupnosti; kurátorské minimum (rozlišení povinností kurátora a sbírky a kurátora výstavy). 
AMG však nebyla v tomto smyslu v průběhu let 2015 ani 2016 oslovena. Ministerstvo kultury posléze splnilo z této části koncepce pouze jeden dílčí bod, a to tím způsobem, že 13. 10. 2016 uspořádalo v Národní galerii seminář pod názvem Nová koncepce rozvoje muzejnictví a její rozvojový potenciál pro galerie a jejich zřizovatele. Na semináři představil základní rysy této koncepce ředitel OMG Pavel Hlubuček, který v podstatě zopakoval některé teze, obsažené již v dřívějším návrhu MK z roku 2005 - registrace/akreditace jako správní řízení, kategorizace v zásadě dle zřizovatelů, pouze teoretická možnost postupu do vyšší kategorie, v každé kategorii bude požadován souhrn určitých standardů (veřejných služeb), registrovaná muzea budou mít přístup $\mathrm{k}$ některým dotačním titulưm a pobídkám (nebude se to týkat Integrovaného systému ochrany).

Prakticky jedinou novinkou se ukázalo být konstatování, že vytvoření systému by mělo být řešeno formou samostatného zákona, nikoliv pouhou novelou zákona č. 122/2000 Sb. Základním podkladem pro realizaci systému by se měl stát výstup ze zmíněného projektu RG a Metodického centra pro výtvarné umění. Protože dosavadní návrhy řešení systému registrace a akreditace nebyly prŕliš vhodné pro muzea, popř. se jich ani netýkaly, byla v roce 2016 vytvořena pro tento účel pracovní skupina AMG, jejímiž členy se stali čtyři zástupci Exekutivy AMG - Ondřej Dostál, Zdeněk Kuchyňka, Luděk Beneš a Richard M. Sicha a dále muzejníci, zabývající se dlouhodobě problematikou muzejní legislativy František Šebek a Dana Veselská. Hned na počátku svého působení připravila tato skupina návrh čtyř základních kritérií pro zařazení muzeí do registru, vycházející pochopitelně z etického kodexu
ICOM i z definice muzeí v zákoně č. 122/2000 Sb.: 1) Instituce vlastní nebo spravuje sbírku muzejní povahy s cílem ji uchovávat a zkvalitňovat, bez ohledu na to, zda je, či není tato sbírka zapsána v CES. 2) Instituce zpřístupňuje sbírku za stanovených podmínek veřejnosti. ${ }^{80}$ 3) Instituce je otevřená veřejnosti a působí ve prospěch společnosti. ${ }^{81}$ 4) Činnost instituce má v principu charakter neziskové organizace. $^{82}$

Tyto čtyři zásady byly schváleny Senátem AMG na jeho zasedání 22. 9. 2016 a pracovní skupina tak měla volné ruce a stanovený směr k další své činnosti. Výstupy ze svých jednání prezentovala také na mezinárodní konferenci Muzeum a změna $V$, která se konala v listopadu roku 2016. Během následujících jednání na podzim 2016 a na jaře 2017 dospěla skupina $\mathrm{k}$ dalším závěrům, které byly poté předloženy muzejní veřejnosti. Jako hlavní cíl registrace stanovila vyhlášení veřejně přístupného registru muzeí, který by oddělil skutečná muzea plnící veškeré muzejní funkce (standardy) od těch, jež sice mají pojem „muzeum“ v názvu, potřebné požadavky však nesplňují. Akreditaci pak pojala jako vyšší stupeň celého procesu, během něhož budou registrovaná

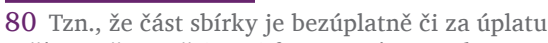
zpřístupněna veřejnosti formou výstav nebo dlouhodobých expozic a je stanovena otevírací doba či způsob zpřístupnění výstav či expozic, pokud není stanovena pravidelná otevírací doba; sbírka je přístupná badatelům, at̉ již reálně nebo prostřednictvím digitálních záznamů.

81 Tzn., že pravidelně informuje veřejnost o nabízených službách a programech, každoročně zveřejňuje výroční zprávu o své činnosti; každoročně zpracovává a odevzdává roční statistický výkaz Kult (MK) 14 - 01; dodržuje etický kodex ICOM a její činnost není v rozporu s právním řádem ČR.

82 Tzn., že organizace své celkové výnosy vynakládá na pokrytí nákladů své činnosti (včetně přiměřené mzdy zaměstnanců). Případný zisk používá na účel, k němuž byla zřízena (na rozvoj této činnosti, což je vymezeno v zakládacím dokumentu), a tento zisk není použit k financování jiných činností. Je-li muzeum organizačním článkem nějakého jiného subjektu (firmy), vede své účetnictví na principu účetního střediska, z něhož je průkazný princip neziskovosti. muzea posouzena a poté zařazena do určitého stupně dosažené kvality vykonávaných činností. Stane se tak na základě hodnocení plnění stanovených kritérií, jimiž budou výkonnostní a profesní standardy. Část z nich bude společná pro všechny kategorie muzeí, další budou pro jednotlivé kategorie specifické. Akreditace bude přidělena pouze na určitou dobu, po jejím uplynutí bude muset muzeum stupeň kvality obhájit, popř. bude moci postoupit na vyšší stupeň nebo naopak svůj původní stupeň kvality ztratit. Základní principy návrhu byly předány Unii zaměstnavatelských svazů, Svazu měst a obcí ČR, Asociaci krajů ČR i Ministerstvu kultury a byly rovněž projednány s RG a s ČV ICOM. Unie zaměstnavatelských svazů pak vzala návrh AMG za svůj a v jejím rámci byla pro tento záměr vytvořena samostatná komise.

V této fázi považovala pracovní skupina AMG za lepší řešení oddělení procesu registrace od akreditace a zejména u fáze akreditace zdůrazňovala její dobrovolnost. Úvahy členů skupiny o počtu kvalitativních stupňů byly často značně odlišné, nakonec však všichni dospěli k názoru, že z hlediska jednoduchosti celého systému by byl ideální počet tří, maximálně čtyř stupňů. Reakreditace (obhajoba dosaženého stupně kvality) by měla probíhat vždy po pěti letech. Muzea by byla rozdělena do 4-5 kategorií, a to na muzea obecná (vlastivědná), specializovaná, muzea umění (galerie), památníky (osobností, událostí atd.), popř. muzea $\mathrm{v}$ prrírodě (skanzeny). Diskutovalo se také o dalším rozčlenění uvnitř kategorií, a to podle rozsahu sbírek nebo počtu zaměstnanců. František Šebek připravil na podzim 2017 návrh základních, tj. společných kritérií, zejména v oblasti managementu včetně public relations 
a marketingu, správy a evidence sbírek, ochrany sbírek, kulturněvzdělávací a vědecko-výzkumné činnosti, edukativních aktivit a služeb pro návštěvníky. Hodnotitelé by v rámci procesu hodnocení měli vždy přihlédnout $\mathrm{k}$ dalším okolnostem a podmínkám, v nichž jednotlivá muzea působí, nikoliv je pouze mechanicky srovnávat. Hlavními podklady pro hodnocení budou výroční zprávy, statistické výkazy, benchmarking muzeí a také speciální dotazníky, jež budou zčásti shodné pro všechny kategorie a zčásti rozdílné. $\mathrm{V}$ případě benchmarkingu se však členové komise shodli na tom, že bude nezbytné odstranit jeho dosavadní nedostatky - nesprávné či dokonce nepravdivé vyplňování výkazu V-Kult (MK) 14-01, nedostatečná kontrola ze strany NIPOS a chybně vypočítané údaje $\mathrm{v}$ testovací verzi benchmarkingu.

Na jaře roku 2018 se situace kolem muzejní legislativy výrazně změnila. Po nástupu nového ministra kultury Antonína Staňka totiž ministerstvo zařadilo do svého legislativního plánu přípravu samostatného zákona o muzeích, který by je konečně mohl podchytit jako instituce, nebot zákon č. 122/2000 Sb. se týkal pouze jedné části jejich činnosti, tj. péči o sbírky. AMG byla přizvána do pracovní skupiny náměstka ministra kultury Vlastimila Ourody, jež začala působit $\mathrm{v}$ podzimních měsících téhož roku, a to spolu se zástupci RG, ČV ICOM, Svazu muzeí $\mathrm{v}$ přírodě a některých státních muzeí. Registrace a akreditace muzeí se stala na základě společné dohody jedním z uzlových bodů připravované legislativní normy, návrhy vypracované pracovní skupinou AMG proto mohly být z velké části při práci „ministerské“ skupiny využity. Na úvod činnosti pracovní skupiny připravil OMG materiál nazvaný Registrace a akreditace muzeí, jenž shrnul a v podstatě zopakoval dosavadní zásady, jež obsahovaly dřívější dílčí návrhy MK doplněné o některé další vyplývající ze zmíněného projektu RG a také z detailně rozpracovaného akreditačního dotazníku, který RG vyhotovila jako návrh pro své členy i pro další galerie v roce $2017 .{ }^{33} \mathrm{~V}$ materiálu OMG byly uvedeny i alternativní návrhy AMG, třebaže většinou okomentované jako obtížně použitelné či př́iliš složité. $\mathrm{Na}$ již dříve nastolených základních principech OMG trval. Poprvé však OMG připustil, že by do registru mohla být zařazena i muzea, jejichž sbírky nejsou zapsány v CES. V materiálu jsou vyjmenována i některá kritéria pro zařazení do jednotlivých kategorií s důrazem na funkčnost managementu, veřejnou prospěšnost a péči o sbírky. Nově - a to bylo potřeba kvitovat s povděkem - sem byla začleněna i další kritéria z oblasti činnosti muzeí - zpř́ístupňování sbírek veřejnosti, akviziční strategie, edukační aktivity a služby návštěvníkům.

AMG reagovala na předložení tohoto materiálu poměrně rozsáhlým připomínkovým dokumentem, v němž vyjádřila spokojenost $\mathrm{s}$ tím, že se odbor začal výrazněji věnovat jednomu ze základních požadavků obsažených v Koncepci rozvoje muzejnictví na léta 2015-2020 a souhlas $s$ některými navrženými principy a závěry. Nadále však trvala na oddělení procesu registrace muzeí od jejich akreditace a zejména na rozdělení muzeí do kategorií dle jejich typu a teprve $\mathrm{v}$ rámci jednotlivých kategorií na přidělení stupně (a značky) kvality. Výrazné

83 Archiv Asociace muzeí a galerií ČR, fond Legislativa - kultura. Registrace (akreditace) a kategorizace muzeí jako jeden proces; Čtyři základní standardizované veřejně prospěšné služby jako základní kritéria pro registraci/ akreditaci (územní, časová, ekonomická a fyzická dostupnost); Registrace jako součást novely zákona č. 122/2000 Sb.; Národní sít muzeí vytvořená z muzejních institucí, které vykonávají největší rozsah veřejných služeb, (národní, zemská). námitky byly vysloveny proti principu v podstatě mechanického a neměnného sestavení Národní sítě muzeí, jež by byla prakticky nedostupná pro regionální i obecní (městská) muzea. Jelikož během prvních zasedání ministerské pracovní skupiny se ukázalo, že se její členové nedokážou shodnout ani na základních zásadách a cílech své činnosti (včetně otázky, zda je samostatný zákon o muzeích vůbec potřebný), byly AMG a RG jako organizace zastupující odbornou veřejnost pověřeny, aby společně vypracovaly základní koncepci nové legislativní normy. Registrace a akreditace muzeí byla přitom uvedena na prvním místě jako základní pilíř a zároveň jako patrně nejspornější součást budoucího zákona.

Na společných jednáních zástupců AMG a RG bylo dosaženo v období od května do záŕí 2019 kompromisu v hlavních zásadách návrhu systému registrace a akreditace, přičemž obě strany musely ustoupit v části svých původních názorů. Společné stanovisko vyjádřené v návrhu, jenž byl rozeslán ostatním členům pracovní komise, nyní vyznělo tak, že proces registrace a akreditace bude spojen, přičemž registrace bude pojata jako správní úkon v gesci Ministerstva kultury, zatímco akreditace přidělení stupně kvality registrovaným muzeím - bude prováděna speciálně vytvořeným odborným orgánem. Zápis do CES bude přitom podmínkou pro zařazení do akreditačního procesu. Při zapsání do registru bude posuzováno pouze plnění čtyř základních funkcí muzea dle návrhu AMG vycházejícího z Etického kodexu ICOM. Stupně kvality - obě strany se dohodly na počtu tř́ stupňů - budou přidělovány vždy na pět let, a to v rámci tří kategorií - všeobecných a specializovaných muzeí a muzeí umění (galerií). Principy hodnocení a hodnotící kritéria 
budou předmětem další diskuse. Výčet podkladů pro akreditaci vychází z původního návrhu AMG: statistické výkazy V-Kult (MK) 14-01, výroční zprávy, anketní dotazníky doplněné obrazovou dokumentací a případně i návštěvy odborné komise v dotyčném muzeu či galerii a na jejich základě vypracovaný odborný posudek. Vytvoření Národní sítě muzeí nemůže probíhat mechanicky, jak je obsaženo v návrhu odboru, nýbrž musí být předmětem široké odborné diskuse. Muzea zařazená do Národní sítě budou plnit specifické úlohy a vykonávat zvláštní agendy, zejména v oblasti metodické a odborné pomoci ostatním muzeím. Standardy, dle nichž bude posuzováno zařazení muzeí do kvalitativních stupňů, by měly být rozšířeny ještě o výstavní a další prezentační, vědecko-výzkumnou a publikační činnost a také o propagaci muzeí a informovanost o jejich činnosti ve vztahu k veřejnosti.

Tento materiál byl prodiskutován na jednání pracovní skupiny v prosinci 2019, jejíž účastníci s ním vyslovili souhlas s jedinou výjimkou: zástupci státních muzeí nesouhlasili s tím, aby do systému registrace a akreditace byla zařazena muzea, která nemají své sbírky zapsané v CES. Ani další jednání pracovní skupiny na počátku roku $2020 \mathrm{v}$ tomto ohledu nepřinesla nic nového, názory na registraci muzeí, ale i na další zásady, jež by měl nový muzejní zákon stanovit, zůstaly diametrálně odlišné a příprava nové legislativní normy pro oblast muzejnictví tak $\mathrm{v}$ době dokončení tohoto článku zůstávala stále na samém počátku.

\section{POUŽITÉ PRAMENY A LITERATURA:}

Archiv Asociace muzeí a galerií ČR, fond Legislativa - kultura. Dopis z Odboru muzeí a galerií Ministerstva kultury ze dne 13. 9. 2005.

Archiv města Plzně, fond Fridolín Macháček.

Archiv Národního muzea, fond Svaz československých muzeí.

CÁSEK, Jiří. Vývoj právní regulace památkové péče [online]. Brno: Masarykova univerzita, Právnická fakulta, 2016/2017 [cit. 2020-04-17]. Dostupný z www: <is.muni.cz/th/wzrvd/ Diplomova-práce_-_elektronicka_verze. pdf $>$. Diplomová práce.

Český lid [online]. 1893, roč. III, s. 372-373 [cit. 2020-04-17]. Dostupný z www: <www.nulk.cz/ek-obsah/ ceskylid-html/ceskylid03>.

DOUŠA, Pavel. Organizace českého muzejnictví 1945-1989. Opava: Slezská univerzita v Opavě, Filozofická fakulta, 2005. Dizertační práce.

FIALOVÁ, Dagmar. Profesní a etické standardy a výkonnostní ukazatele muzejní práce. Národní systém muzeí jako nástroj udržení společné odborné a etické základny muzeí $v \check{C} R$. Praha: Asociace muzeí a galerií ČR, 2003.

ISBN 80-86611-02-7.

HROMÁDKOVÁ, Kateřina. Karel Václav Adámek a jeho činnost muzejní a muzeologická. [online]. Pardubice: Univerzita

Pardubice, Filozofická fakulta, 2007/2008 [cit. 2020-04-17]. Dostupný z www: <dk.upc.cz/bitstream/ handle/10195/19389(HromadkovaK_ kabel\%20 Vaclav_FS_2008.

pdf? sequence $=1$ isAlcrved $=\mathrm{y}>$. Diplomová práce.

Jak muzejní akreditační program pracuje, včetně práv a povinností registrovaných a akreditovaných muzeí. Praha: NIPOS, nedat.

JANEČKOVÁ, Jitka. Mráz kopřivu nespálí. Život a dílo Fridolína Macháčka a Václava Vojtíška ve vzájemné korespondenci z let 1905-1954. Plzeň: Scriptorium, 2014. ISBN 978-80-88013-01-3.

KOMÁRKOVÁ, Anna. Registrační systém muzeí. Zjištění používaných metod evaluace $v$ zahraničí. Nedat. (2010).

MASON, Timothy a Jane WEEKS. From Australia to Zanzibar. Museums Standard Schemes Overseas. A research project for ressource. London: The Council for Museums nad Libraries, 2002.

ŠEBEK, František. Muzea a galerie. Nedat. ŠPÉT, Jiří. Formování a rozvoj socialistického muzejnictví v ČSR (1945-1985). Praha: Národní muzeum, 1988.

ŠPÉT, Jiří. Muzea ve vývoji společnosti a národní kultury. Praha, 1983.

ŠPÉT, Jiří. Přehled vývoje českého muzejnictví I. (do roku 1945). Brno: Masarykova univerzita, 2003. ISBN 80-210-3206-5. 


\section{LUDĚK BENEŠ}

nezávislý muzejník, Mladá Boleslav, Česká republika

ludben@email.cz

Luděk Beneš, nar. 1954, v letech 1974-1979 vystudoval obor historieněmčina na Filozofické fakultě Univerzity Palackého v Olomouci. V letech 1979-1990 puisobil jako historik a 1990-2017 jako ředitel Okresního muzea Mladá Boleslav (od 2003 Muzea Mladoboleslavska). Mezi lety 1993-1997 a 2000-2018 byl členem Exekutivy Asociace muzeí a galerií ČR, 2012-2015 její předseda. Zaměřuje se na regionální dějiny 19. a 20. století a na významné osobnosti regionu Mladoboleslavska. Je autorem lexikonu Osobnosti Mladoboleslavska a řady publikací i časopiseckých statí k historii Mladoboleslavska, spoluautorem monografie Mladoboleslavsko v proměnách času a dalších publikací s regionální tématikou.

Luděk Beneš, born 1954, studied History and German Language at the Faculty of Arts of Palacký University in Olomouc in 1974-1979. In 1979-1990 he worked as historian and in 1990-2017 as director of the District Museum in Mladá Boleslav (since 2003 Museum of Mladá Boleslav Region). In 1993-1997 and 2000-2018 he was member and in
2012-2015 chairman of the Executive Board of the Czech Association of Museums and Galleries. He specialises in the 19th and 20th century regional history and significant personalities in the region of Mladá Boleslav. He is author of the lexicon Osobnosti Mladoboleslavska (Personalities of Mladá Boleslav Region) and many publications and journal articles on the history of Mladá Boleslav Region, co-author of the monograph Mladoboleslavsko v proměnách času (Mladá Boleslav Region in the course of time) and other publications on regional topics.

Toto dílo lze užít v souladu s licenčními podmínkami Creative Commons BY-SA 4.0 International (https://creativecommons.org/licenses/by-sa/4.0/ legalcode). Uvedené se nevztahuje na díla či prvky (např. obrazovou či fotografickou dokumentaci), které jsou v díle užity na základě smluvní licence nebo výjimky či omezení př́slušných práv. 